\title{
Seroprevalence and risk factors associated with Neospora caninum in crossbred dairy cows in Uberlândia
}

\section{Soroprevalência e fatores de risco associados ao Neospora caninum em vacas leiteiras mestiças em Uberlândia, Minas Gerais}

\author{
Nayara Resende Nasciutti ${ }^{1}$; Patrícia Magalhães de Oliveira'; \\ Vinícius de Morais Barbosa ${ }^{1}$; Selwyn Arlington Headley²; \\ Felipe Gonçalves Garcia ${ }^{1}$; Murilo Vieira da Silva ${ }^{3}$; Flávia Batista Ferreira ${ }^{3}$; \\ Tiago Wilson Patriarca Mineo ${ }^{3}$; João Paulo Elsen Saut ${ }^{1 *}$
}

\begin{abstract}
Neospora caninum causes reproductive disorders in dairy cattle such as repeat breeding, abortion, and anestrus, which are risk factors associated with the seroprevalence of $N$. caninum in Brazil and worldwide. This study aimed to verify the risk factors related to the seroprevalence of Neospora caninum in crossbred dairy cows in the city of Uberlândia, Minas Gerais. During, January to July 2013, 740 blood samples were collected from 57 herds with a history of reproductive disorders and determinations of antibody titers against $N$. caninum were obtained by ELISA assay. The seroprevalence of $N$. caninum was $18.4 \%(136 / 740)$. Risk factors for $N$. caninum were cows greater than 2 years of age $(\mathrm{P}=0.034)$, mechanical milking $(\mathrm{P}=0.012)$, and frequent purchase of animals $(\mathrm{P}=0.004)$, in addition to individual history of abortion $(\mathrm{P}=0.007)$ and repeat breeding $(\mathrm{P}=0.030)$. The highest probability of occurrence of associated risk factors was associated with individual history of abortion and repeated breeding and the frequent purchase of animals, with odds of 12.8, 5.9, and 3.8 times, respectively. In conclusion, the risk factors associated with $N$. caninum: members of the female sex and cows with more than 2 yearsof-age, mechanical milking, and the frequent purchase of animals, in addition to individual history of abortion and repeated breeding.
\end{abstract}

Key words: Abortion. Cattle. Neosporosis.

\section{Resumo}

Neospora caninum causa distúrbios reprodutivos na bovinocultura de leite como repetição de cio, abortamento e anestro, que são fatores de risco associados à soroprevalência do Neospora caninum no Brasil e no mundo. Objetivou-se verificar os fatores de risco relacionados à soroprevalência do Neospora caninum no município de Uberlândia, Minas Gerais em vacas leiteiras mestiças. No período de janeiro a julho de 2013 foram colhidas 740 amostras de sangue de vacas, em 57 propriedades com

1 Médicos Veterinários, Laboratório de Saúde em Grandes Animais, Faculdade de Medicina Veterinária, Universidade Federal de Uberlândia, UFU, Uberlândia, MG, Brasil. E-mail: nayaranasciutti@yahoo.com.br; pmo.veterinaria@yahoo.com.br; vinicius.barbosa6@ hotmail.com; felipe_g_garcia@hotmail.com; jpsaut@ufu.br

2 Prof. Dr., Laboratório de Virologia Animal, Departamento de Medicina Veterinária Preventiva, Universidade Estadual de Londrina, UEL, Londrina, PR, Brasil. E-mail: selwyn.headley@uel.br

3 Médicos Veterinários, Laboratório de Imunoparasitologia "Dr Mário Endsfeldz Camargo", Departamento de Imunologia, Instituto de Ciências Biomédicas, UFU, Uberlândia, MG, Brasil. E-mail: murilo.vieira@ufu.br; flaviabatistaf@yahoo.com.br; tiago.mineo@ufu.br

* Author for correspondence 
histórico de problemas reprodutivos e as determinações dos anticorpos contra o N. caninum foram obtidos pela técnica de ELISA. A soroprevalência foi de 18,4\% (136/740) de positivos para o N. caninum. Os fatores de risco associados para o $N$. caninum foram fêmeas maiores de dois anos $(P=0,034)$, ordenha mecânica $(P=0,012)$, compra frequente de animais $(P=0,004)$, além do histórico individual de abortamento $(P=0,007)$ e repetição de cio $(P=0,030)$. A maior probabilidade de ocorrência de fatores de risco associados foram: histórico de abortamento e repetição de cio individual e a compra frequente de animais, respectivamente, com chances de 12,8; 5,9 e 3,8 vezes. Concluiu-se que existem fatores de risco associados para o $N$. caninum: fêmeas maiores de dois anos, ordenha mecânica, compra frequente de animais, além do histórico individual de abortamento e repetição de cio.

Palavras-chave: Abortamento. Bovinos. Neosporose.

\section{Introduction}

There are several causes of embryonic loss and abortions in cattle, and the likely etiologic agents of these diseases should be identified (SARTOR et al., 2005). Neospora caninum is considered as one of the main causative agents of reproductive disorders (SARTOR et al., 2005) and is responsible for economic losses in dairy cattle resulting from abortions around the $5^{\text {th }}$ and $6^{\text {th }}$ months of pregnancy (MELO et al., 2006).

Neosporosis has been identified in several countries, with the following reported seroprevalences: Morocco - 8.52\% (15/176) (LUCCHESE et al., 2016), China - $17.14 \%$ (769/4487) (SUN et al., 2015), Algeria - 19.64\% (157/799) (GHALMI et al., 2012), Vietnam - 19\% (25/130) (DUONG et al., 2008), Japan - 5.7\% $(139 / 2420)$ (KOIWAI et al., 2006), Thailand $5.49 \%(30 / 549)$ (KYAW et al., 2004), United States - $10.34 \%(9 / 87)$ to $32.11 \%(105 / 327)$ (ORTEGA et al., 2007), Venezuela - 11.3\% (52/459) (LISTAALVES et al., 2006), Paraguay - 29.8\% (262/879) (OSAWA et al., 2002), and Spain - 35.9\% (402/1121) (QUINTANILLA-GOZALO et al., 1999).

Antibodies against $N$. caninum were detected in serum from dairy cattle from herds located in several Brazilian states (RAGOZO et al., 2003), and a seroprevalence of $16.83 \%(101 / 600)$ was reported in the states of São Paulo and Minas Gerais (COSTA et al., 2001). Santos et al. (2009) reported a seroprevalence of $46.25 \%$ in calves and heifers from dairy herds in the state of Minas Gerais, and there has been a report of $10 \%(7 / 69)$ to $20 \%$ (34/174) prevalence of $N$. caninum antibodies in dairy cows with a history of reproductive problems in properties in the region of the Triângulo Mineiro, Minas Gerais (MINEO et al., 2006).

More recently, several studies were done to identify the risk factors associated with the seroprevalence of $N$. caninum, with the aim to prevent and reduce the occurrence of neosporosis in herds. Poor quality of water, the presence of dogs, poor hygiene conditions, and a history of abortions have already been reported as risk factors (GHALMI et al., 2012; SUN et al., 2015). In Brazil, the type of herd, method of herd management, presence of definitive hosts (SARTOR et al., 2005), and reproductive problems such as repeated breeding, history of abortion, and anestrus (BRUHN et al., 2013) have been reported as risk factors. Abortion is considered the main clinical manifestation of cows infected with $N$. caninum (HUSSIEN et al., 2012).

Accordingly, the aim of this study was to identify the risk factors associated with seroprevalence of $N$. caninum in crossbred cows from the city of Uberlândia, Minas Gerais.

\section{Materials and Methods}

Study area

The study was conducted in the city of Uberlândia, located in the state of Minas Gerais, Southeastern Brazil, in the microregion of the Triângulo Mineiro, between January and July 2013. 
A total of 57 properties distributed in five districts of the municipality (Martinésia, Cruzeiro dos Peixotos, rural perimeter of Uberlândia, Tapuirama and Miraporanga), were assessed.

\section{Inclusion criteria}

Only properties of the municipality with a history of reproductive problems, defined by abortion observed in any stage of pregnancy and repeated breeding, were included in the experiment. A maximum of 15 adult lactating crossbred dairy cows, born on the farm and raised under an extensive rearing system, were randomly selected for the study. These animals were immunized against brucellosis and foot-and-mouth disease, according to the requirements of the Brazilian Ministry of Agriculture, Livestock and Supply (MAPA).

\section{Epidemiological survey}

To identify potential associated risk factors, information concerning the following was collected from the properties: type of farming (dairy/mixed), total number of cows on the property $(\leq 100 />100$ animals), number of cows over two years old $(\leq 100 />100$ animals), total herd population ( $\leq 100 />100$ animals), type of milking (manual/ mechanical), frequent purchase of animals (no/ yes), completion of quarantine (no/yes), presence of birthing paddock (no/yes), presence of dogs (no/ yes), history of abortion on the property (no/yes), repeat breeding, and history of individual abortion (no/yes).

\section{Serology}

The properties were visited once for the collection of blood sample. Blood was collected by caudal vein puncture, and the samples were collected in vacuum tubes without anticoagulant. The serum aliquots were maintained frozen and subsequently used in the enzyme-linked immunosorbent assay (ELISA).

\section{Antigen}

N. caninum tachyzoites (strain NC-1) were maintained under the same conditions by continuous passage of HeLa cells at $37^{\circ} \mathrm{C}$ and $5 \% \mathrm{CO}_{2}$ in RPMI medium supplemented with $25 \mathrm{mM}$ HEPES, $2 \mathrm{mM}$ L-glutamine, $3 \mathrm{mM}$ sodium bicarbonate, and an antibiotic/antimycotic solution (penicillin $100 \mathrm{IU} /$ $\mathrm{mL}$, streptomycin $100 \mu \mathrm{g} / \mathrm{mL}$ and amphotericin B $0.25 \mathrm{~g} / \mathrm{mL}$; Gibco) (MINEO et al., 1980).

A suspension of the parasite was washed twice $\left(720 \times g, 10\right.$ minutes, $\left.4{ }^{\circ} \mathrm{C}\right)$ in phosphate buffered saline (PBS $0.01 \mathrm{M}, \mathrm{pH} 7.2$ ), treated with protease inhibitors (Complete, Roche) and then subjected to 10 cycles of freezing-thawing and sonication $(60 \mathrm{~Hz}$, amplitude of $90 \%$, ice bath). After centrifugation $\left(10000 \times g, 30 \mathrm{~min}, 4{ }^{\circ} \mathrm{C}\right)$, the supernatant was collected and filtered through a $0.22 \mathrm{~m}$ membrane (Millex, Millipore, USA). The supernatant, containing soluble $N$. caninum antigens (NLA), was collected and the concentration of protein was estimated using the Bradford assay. The aliquots were stored at $-20{ }^{\circ} \mathrm{C}$ until completion of the assay.

\section{Indirect ELISA}

Indirect ELISA was used to detect IgG antibodies as described by Silva et al. (2007), with modifications. High affinity microtiter plates were coated with NLA $(10 \mu \mathrm{g} / \mathrm{ml})$ in $0.06 \mathrm{M}$ carbonate $(\mathrm{pH}$ 9.6) overnight at $4{ }^{\circ} \mathrm{C}$. The plates were washed three times with PBS containing $0.05 \%$ Tween 20 (PBS-T) and blocked with PBS-T plus 5\% MOLICO (PBSTM) for 1 hour at room temperature. Subsequently, after three more washes, the plates were incubated with serum samples diluted in PBS-TM (1: 200) for 1 hour at $37^{\circ} \mathrm{C}$, with known seropositive and seronegative samples as the reaction control group. Plates were washed six times and incubated for 1 hour at $37{ }^{\circ} \mathrm{C}$ after addition of peroxidase-labeled IgG anti-bovine antibody, diluted in PBS-TM. The reaction was developed after a new wash cycle by adding the enzymatic substrate $(0.03 \%$ $\mathrm{H}_{2} \mathrm{O}_{2}$ ) and chromogen (0.01 M 2,2-azino-bis-3- 
ethyl-benzothiazolinesulfonic acid [ABTS: Sigma Chemical Co.]) in $0.07 \mathrm{M}$ citrate-phosphate buffer (pH 4.2). Optical density (OD) was read at $405 \mathrm{~nm}$ after a $40 \mathrm{~min}$ incubation period on a plate reader (M2e, Molecular Devices, USA).

\section{ELISA index values}

The cutoff of the reaction was determined by the mean optical density (OD) with negative control serum with three deviations. Antibody titers were expressed by the ELISA index value, according to the formula IE = OD sample/OD cutoff, as described by Silva et al. (2007). Samples with ELISA index $\geq$ 1.2 were considered positive.

\section{Statistical analysis}

Using the binary logistic regression model in the SPSS program, the result (positive/negative) the output variable was selected as the dependent variable (binary) and as covariates, predictive variables: type of farming (dairy or mixed), total number of cows in the property ( $\leq 100 />100$ animals), number of cows over 2 years old $(\leq 100 />100$ animals), total number of herd $(\leq 100 />100$ animals), type of milking (manual or mechanical), frequent purchase of animals and completion of quarantine, presence of birthing paddock (yes/no), and presence of reproductive problems such as abortion and repeat breeding (yes/no). The HosmerLemeshow goodness of fit test was used to evaluate the model and compare the observed and expected frequencies.

\section{Ethics Committee}

The study was approved by the Ethics Committee on Animal Use (CEUA) of the Universidade Federal de Uberlândia under protocol no. 011/13.

\section{Results}

Seven hundred and forty blood samples were collected from the 57 properties used in the experiment. The properties were divided according to district: Martinésia $(n=98)$, Cruzeiro dos Peixotos $(n=88)$, rural perimeter of Uberlândia $(n=277)$, Tapuirama $(n=64)$, and Miraporanga $(n=213)$. The seroprevalence for $N$. caninum was $18.4 \%(136 / 740)$ (Table 1), with prevalence in the districts ranging between $12.2 \%$ and $24.2 \%: 14.3 \%$ (14/98) in Martinésia, 20.5\% (18/88) in Cruzeiro dos Peixotos, $24.2 \%(67 / 277)$ in the rural perimeter of Uberlândia, $17.2 \%(11 / 64)$ in Tapuirama and $12.2 \%$ (26/213) in Miraporanga.

Of the 12 factors analyzed (Table 1), five risk factors associated with seroprevalence of $N$. caninum were identified. Animals from properties with more than 100 cows over two years old had a threefold higher risk and the frequent purchase of animals was associated with a 3.8 -fold higher risk. Individual histories of abortion increased the risk 12.8-fold and repeated breeding in animals by 5.9 fold. Manual milking was associated with a $49.4 \%$ lower risk than was mechanical milking (Table 2). All the properties had dogs in their premises. 
Table 1. Percentage distribution of potential risk factors associated with seroprevalence for Neospora caninum in unvaccinated crossbred cows in the city of Uberlândia, Minas Gerais, Brazil, by the ELISA technique.

\begin{tabular}{|c|c|c|c|}
\hline Variables & Animals tested & Positive & Seroprevalence $(\%)$ \\
\hline \multicolumn{4}{|l|}{ Type of farm } \\
\hline Dairy & 583 & 111 & 19.0 \\
\hline Mixed & 157 & 25 & 15.9 \\
\hline \multicolumn{4}{|l|}{ Total number of cows } \\
\hline$\leq 100$ & 317 & 53 & 16.7 \\
\hline$>100$ & 423 & 83 & 19.6 \\
\hline \multicolumn{4}{|c|}{ Total number of cows $>2$ years old } \\
\hline$\leq 100$ & 506 & 100 & 19.8 \\
\hline$>100$ & 234 & 36 & 15.4 \\
\hline \multicolumn{4}{|l|}{ Total number of animals } \\
\hline$\leq 100$ & 170 & 28 & 16.5 \\
\hline$>100$ & 570 & 108 & 18.9 \\
\hline \multicolumn{4}{|l|}{ Type of milking } \\
\hline Manual & 380 & 61 & 16.1 \\
\hline Mechanical & 360 & 75 & 20.8 \\
\hline \multicolumn{4}{|l|}{ Purchase of animals property } \\
\hline No & 69 & 15 & 21.7 \\
\hline Yes & 671 & 121 & 18.0 \\
\hline \multicolumn{4}{|l|}{ Quarantine - property } \\
\hline No & 550 & 107 & 19.5 \\
\hline Yes & 190 & 29 & 15.3 \\
\hline \multicolumn{4}{|l|}{ History of abortion- property } \\
\hline No & 266 & 42 & 15.8 \\
\hline Yes & 474 & 94 & 19.8 \\
\hline \multicolumn{4}{|l|}{ Birthing paddock } \\
\hline No & 353 & 70 & 19.8 \\
\hline Yes & 387 & 66 & 17.1 \\
\hline \multicolumn{4}{|l|}{ History of abortion- animal } \\
\hline No & 724 & 134 & 18.5 \\
\hline Yes & 16 & 2 & 12.5 \\
\hline \multicolumn{4}{|l|}{ Repeated breeding - animal } \\
\hline No & 716 & 132 & 18.4 \\
\hline Yes & 24 & 4 & 16.7 \\
\hline
\end{tabular}

*Presence of dogs in $100 \%$ of the properties.

Table 2. Risk factors associated with seroprevalence for Neospora caninum in unvaccinated crossbred cows in the city of Uberlândia, Minas Gerais, Brazil.

\begin{tabular}{lcccc}
\hline \multicolumn{1}{c}{ Risk Factors } & Coefficient & P-value & Exp (B) Odds ratio & $95 \%$ C.I. \\
\hline Constant & -6.857 & & & \\
Females $>$ 2 years old & 1.113 & 0.034 & 3.042 & $(1.088-8.507)$ \\
Type of milking & -0.682 & 0.012 & 0.506 & $(0.296-0.863)$ \\
Purchase of animals & 1.335 & 0.004 & 3.800 & $(1.545-9.345)$ \\
History of abortion - animal & 2.552 & 0.007 & 12.830 & $(2.041-80.632)$ \\
Repeat breeding - animal & 1.782 & 0.030 & 5.941 & $(1.192-29.608)$ \\
\hline
\end{tabular}

* $\operatorname{Exp}(\mathrm{B})$ - adjusted Odds ratio, with $\operatorname{Exp}(\mathrm{B})>1$ indicating that as the predictor increases, the probability of an outcome increases; a value less than 1 indicates that as the predictor increases, the likelihood of an outcome decreases. 


\section{Discussion}

The region of the Triângulo Mineiro, where the city of Uberlandia is located, has an important role in beef and milk production. However, as with various regions in Brazil, there is a lack of epidemiological data relative to diseases of cattle. This is exacerbated in the case of diseases that affect the reproductive performance of herds. Consequently, this study constitutes an important contribution to the identification of the seroprevalence of neosporosis, using representative and well distributed sampling of the Uberlândia region, which has a cattle herd of 234490 animals, 78904 of which are cows (34 336 heifers between 12 and 24 months old and 28244 heifers over 24 months old) according to data from the Minas Gerais Institute of Agriculture (IMA, 2012).

The seroprevalence in properties with a history of reproductive problems and mostly extensive breeding systems was $18.4 \%$ (136/740). This prevalence is similar to that revealed by surveys conducted in the state of Minas Gerais (COSTA et al., 2001; MINEO et al., 2006) and from other states of Brazil (BENETTI et al., 2009; CORBELLINI et al., 2006; MELO et al., 2006; RAGOZO et al., 2003; SOUSA et al., 2012). There are reports of higher prevalence in cows aged less than 24 months: $43.66 \%$ (93/213) and 47.97\% (154/321) in two dairy herds in Minas Gerais (SANTOS et al., 2009), and $50.4 \%(412 / 812)$ in dairy cattle in the state of Maranhão (TEIXEIRA et al., 2010).

In other countries, higher seroprevalences of $N$. caninum were reported in dairy cattle than that determined in the present study, varying between 19.64\% (GHALMI et al., 2012) and 35.2\% (TALAFHA; AL-MAJALI, 2013); however, lower seroprevalences of $5.49 \%$ (KYAW et al., 2004) to $8.52 \%$ (LUCCHESE et al., 2016) were also reported.

The risk factors identified in this study, such as the number of cows over two years old, abortion history, and frequent purchase of animals were previously reported (GHALMI et al., 2012; SUN et al., 2015). The main clinical manifestation of cattle infected with $N$. caninum is abortion (HUSSIEN et al., 2012), which was also observed in this study, because the animals that presented a history of abortion had a 12.8 fold greater risk of infection. Although abortion is a clinical sign present in neosporosis, it may be due to other infectious causes, that could be either bacterial (e.g. Brucella, Leptospira) and/or viral (e.g. BoHV-1, BVDV) (LUCCHESE et al., 2016).

The fact that $N$. caninum seropositive animals may not present a history of abortion may be due to undetected abortions, possibly at the beginning of pregnancy, or due to embryo resorption. This reinforces the importance of other risk factors such as individual repeated breeding, which increased the risk 5.9 fold in this study. This clinical sign was associated with the seroprevalence of $N$. caninum, as was previously described in dairy cattle from southeastern Brazil (BRUHN et al., 2013). Dogs were constantly present on the properties, and could be infected due to the ingestion of tissue containing bradyzoites (DUBEY et al., 2007).

As with abortion, repeated breeding also has other infectious causes such as campylobacteriosis, trichomoniasis, and genital mycoplasmosis, as well as non-infectious causes such as trauma, genetic and hormonal disorders, and ovarian cysts (JUNQUEIRA; ALFIERI, 2006).

The presence of dogs is considered a risk factor, as they are the definitive hosts of $N$. caninum ( DUBEY et al., 2007; GHALMI et al., 2012). The resistant stage of the parasite, the oocyst, is excreted in the feces of dogs unsporulated (LINDSAY et al., 1999; MCALLISTER et al., 1998). N. caninum is transmitted in cattle by horizontal transmission by means of ingestion of sporulated $N$. caninum oocysts ( DUBEY et al., 2006).

In the present study, the presence of at least one dog as companion or working dogs was observed on all properties, which may have contributed to the prevalence of $N$. caninum on the farms. The 
presence of dogs is common on properties in Brazil and there is little concern on the part of the owners, or even veterinarians; there is no specific legislation regarding the control or prohibition of access of these animals to cattle breeding grounds.

The frequent purchase of animals had a 3.8 fold higher risk when animals were imported from other farms, representing a more elevated likelihood of introducing infected animals on the property, as described by Schares et al. (2004). The proportion of recently purchased animals stood at $90.7 \%$ $(671 / 740)$ of the properties, as this is a common practice among owners in this region; this was done without performing diagnostic tests and quarantine. In the present study, only $34.5 \%(190 / 550)$ of the cows came from quarantined properties.

Animals from properties with more than 100 cows that were more than two years of age had a threefold higher risk of being infected, which could be related to the constant presence of animals in milk production. Factors predisposing herds to infection by $N$. caninum were found in 19-30 month old cows (MELO et al., 2001), and these authors stated that there is greater productive pressure (more stress) in herds of $\mathrm{A} / \mathrm{B}$ milk producers.

The fact that manual milking was associated with a $49.4 \%$ lower risk than was mechanical milking may be correlated to the hygiene conditions at small properties. Ghalmi et al. (2012) indicated that cattle populations that inhabited a poor environment had a higher risk associated with $N$. caninum infection than did populations inhabiting sites with good hygiene practices.

Important predisposing factors, such as the water quality on the property, were also described. Running water was reported as a possible source of infection for cattle (SUN et al., 2015) because, according to these authors, cattle could consume water contaminated with $N$. caninum oocysts from feces of infected dogs. Dogs can have access to drinking water and at the same time defecate within or near the water source.
In the present study, the origin of the water was not considered, because most properties used more than one water source. However, it should be emphasized that according to the Instituto Trata Brasil (OLIVEIRA, 2017), the municipality of Uberlândia ranks second with respect to sanitation among the 100 largest cities of Brazil, in terms of the evolution of the indicators water, sewage, investments, and water loss. According to the Municipal Department of water and sewage in Uberlândia (DMAE, 2010), the municipality has the capacity to treat $100 \%$ of the sewage collected, with $98 \%$ of the total produced sewage collected in Uberlândia, including the districts of Miraporanga, Tapuirama, Martinésia, Cruzeiro dos Peixotos, and the rural area.

\section{Conclusion}

It was concluded that the risk factors associated with $N$. caninum are the presence of cows older than two years, mechanical milking, and the frequent purchase of cattle, as well as an individual history of abortion and repeated breeding.

\section{Acknowledgments}

We acknowledge the Fundação de Amparo à Pesquisa do Estado de Minas Gerais - FAPEMIG, the Conselho Nacional de Desenvolvimento Cientifico e Tecnológico - CNPq, and the Coordenação de Aperfeiçoamento de Pessoal de Nivel Superior - CAPES for financial support and granted scholarships.

\section{References}

BENETTI, A. H.; SCHEIN, F. B.; SANTOS, T. R. dos; TONIOLlO, G. H.; COSTA, A. J. da; MINEO, J. R.; LOBATO, J.; SILVA, D. A. de O.; GENNARI, S. M. Pesquisa de anticorpos anti-Neospora caninum em bovinos leiteiros, cães e trabalhadores rurais da região Sudoeste do Estado de Mato Grosso. Revista Brasileira de Parasitologia Veterinária, São Paulo, v. 18, p. 29-33, 2009. Suplemento 1. 
BRUHN, F. R.P.; DAHER, D. O.; LOPES, E.; BARBIERI, J. M.; ROCHA, C. M. B. M.; GUIMARÃES, A. M. Factors associated with seroprevalence of Neospora caninum in dairy cattle in southeastern Brazil. Tropical Animal Health and Production, Edinburgh, v. 45, n. 5, p. 1093-1098, 2013.

CORBELLINI, L. G.; SMITH, D. R.; PESCADOR, C. A.; SCHMITZ, M.; CORREA, A.; STEFFEN, D. J.; DRIEMEIER, D. Herd-level risk factors for Neospora caninum seroprevalence in dairy farms in southern Brazil. Preventive Veterinary Medicine, Amsterdam. v. 74, n. 2-3, p. 130-141, 2006.

COSTA, G. H. N.; CABRAL, D. D.; VARANDAS, N. P.; SOBRAL, E. de A.; BORGES, F. de A.; CASTAGNOLLI, K. C. Frequência de anticorpos anti-Neospora caninum e anti Toxoplasma gondii em soros de bovinos pertencentes aos estados de São Paulo e de Minas Gerais. Semina: Ciências Agrárias, Londrina, v. 22, n. 1, p. 61-66, 2001.

DEPARTAMENTO MUNICIPAL DE ÁGUA E ESGOTO DE UBERLÂNDIA - DMAE. Esgoto. Uberlândia. 2010. Disponível em: <http://www.dmae. mg.gov.br/?pagina $=$ Conteudo\&id $=767>$. Acesso em: 20 maio 2017.

DUBEY, J. P.; BUXTON, D.; WOUDA, W. Pathogenesis of bovine neosporosis. Journal of Comparative Pathology, Amsterdam, v. 134, n. 4, p. 267-289, 2006.

DUBEY, J. P.; SCHARES, G.; ORTEGA-MORA, L. M. Epidemiology and control of neosporosis and Neospora caninum. Clinical Microbiology Reviews, Washington, v. 20, n. 2, p. 323-367, 2007.

DUONG, M. C.; ALENIUS, S.; HUONG, L. T. T.; BJÖRKMAN, C. Prevalence of Neospora caninum and bovine viral diarrhoea virus in dairy cows in Southern Vietnam. The Veterinary Journal, Amsterdam, v. 175, n. 3, p. 390-394, 2008.

GHALMI, F.; CHINA, B.; GHALMI, A.; HAMMITOUCHE, D.; LOSSON, B. Study of the risk factors associated with Neospora caninum seroprevalence in Algerian cattle populations. Research in Veterinary Science, Kidlington, v. 93, n. 2, p. 655-661, 2012.

HUSSIEN, M. O.; ELFAHAL, A. M.; ENAN, K. A.; MOHAMMED, M. S.; IBRAHIM, A. M.; TAHA, K. M.; EL-HUSSEIN, A. M. Seroprevalence of Neospora caninum in cattle in Sudan. Veterinary World, Wilmington, v. 5, n. 8, p. 465-468, 2012.

INSTITUTO MINEIRO DE AGROPECUÁRIA IMA. Secretaria municipal de agropecuária. Prefeitura de Uberlândia. Uberlândia-MG Rebanho bovino2007/2012. Uberlândia, 2012. Disponível em: $<$ http://www.uberlandia.mg.gov.br/uploads/cms_b_ arquivos/15148.pdf>. Acesso em: 20 maio 2017.

JUNQUEIRA, J. R. C.; ALFIERI, A. A. Falhas da reprodução na pecuária bovina de corte com ênfase para causas infecciosas. Semina: Ciências Agrárias, Londrina, v. 27, n. 2, p. 289-298, 2006.

KOIWAI, M.; HAMAOKA, T.; HARITANI, M.; SHIMIZU, S.; ZENIYA, Y.; ETO, M.; YOKOYAMA, R.; TSUTSUI, T.; KIMURA, K.; YAMANE, I. Nationwide seroprevalence of Neospora caninum among dairy cattle in Japan. Veterinary Parasitology, Amsterdam, v. 135, n. 2, p. 175-179, 2006.

KYAW, T.; VIRAKUL, P.; MUANGYAI, M.; SUWIMONTEERABUTR, J. Neospora caninum seroprevalence in dairy cattle in central Thailand. Veterinary Parasitology, Amsterdam, v. 121, n.3-4, p. 255-263, 2004.

LINDSAY, D. S.; DUBEY, J. P.; DUNCAN, R. B. Confirmation that the dog is a definitive host for Neospora caninum. Veterinary Parasitology, Amsterdam v. 82, n. 4, p. 327-333, 1999.

LISTA-ALVES, D.; PALOMARES-NAVEDA, R.; GARCIA, F.; OBANDO, C.; ARRIETA, D.; HOET, A. E. Serological evidence of Neospora caninum in dual-purpose cattle herds in Venezuela. Veterinary Parasitology, Amsterdam, v. 136, n. 3-4, p. 347-349, 2006.

LUCCHESE, L.; BENKIRANE, A.; HAKIMI, I.; IDRISSI, A. E.; NATALE, A. Seroprevalence study of the main causes of abortion in dairy cattle in Morocco. Veterinaria Italiana, Téramo, v. 52, n. 1, p. 13-19, 2016.

MCALLISTER, M. M.; DUBEY, J. P.; LINDSAY, D. S.; JOLLEY, W. R.; WILLS, R. A.; MCGUIRE, A. M. Dogs are definitive hosts of Neospora caninum. International Journal for Parasitology, Amsterdam, v. 28, p. 14731478, 1998.

MELO, C. B.; LEITE, R. C.; SOUZA, G. N.; LEITE, R. C. Frequência de infecção por Neospora caninum em dois diferentes sistemas de produção de leite e fatores predisponentes à infecção em bovinos em Minas Gerais. Revista Brasileira de Parasitologia Veterinária, São Paulo, v. 10, n. 2, p. 67-74, 2001.

MELO, D. P. G.; SILVA, A. C.; ORTEGA-MORA, L. M.; BASTOS, S. A.; BOAVENTURA, C. M. Prevalência de anticorpos anti-Neospora caninum em bovinos das microrregiões de Goiânia e Anápolis, Goiás, Brasil. Revista Brasileira de Parasitologia Veterinária, São Paulo, v. 15, n. 3, p. 105-109, 2006.

MINEO, J. R.; CAMARGO, M. E.; FERREIRA, A. W. Enzyme-linked immunosorbent assay for antibodies to Toxoplasma gondii polysaccharides in human 
toxoplasmosis. Infection and Immunity, Washington, v. 27, n. 2, p. 283-287, 1980.

MINEO, T. W. P.; ALENIUS, S.; NASLUND, K.; MONTASSIER, H. J.; BJORKMAN, C. Distribution of antibodies against Neospora caninum, BVDV and BHV1 among cows in brazilian dairy herds with reproductive disorders. Revista Brasileira de Parasitologia Veterinária, São Paulo, v. 15, n. 4, p. 188-192, 2006.

OLIVEIRA, G. TRATABRASIL. Ranking do Saneamento- As 100 maiores cidades do Brasil (SNIS 2015). Uberlândia: [s.n.], 2017. Disponível em: <http:// www.tratabrasil.org.br/datafiles/estudos/ranking/2017/ tabela-100-cidades.pdf. Uberlândia>. Acesso em: 20 maio 2017.

ORTEGA, Y. R.; TORRES, M. P.; MENA, K. D. Presence of Neospora caninum specific antibodies in three dairy farms in Georgia and two in Texas. Veterinary Parasitology, Amsterdam, v. 144, n. 3-4, p. 353-355, 2007.

OSAWA, T.; WASTLING, J.; ACOSTA, L.; ORTELLADO, C.; IBARRA, J.; INNES, E. A Seroprevalence of Neospora caninum infection in dairy and beef cattle in Paraguay. Veterinary Parasitology, Amsterdam, v. 110, n. 1-2, p. 17-23, 2002.

QUINTANILLA-GOZALO, A.; PEREIRA-BUENO, J.; TABARÉS, E.; INNES, E. A.; GONZÁLEZ-PANIELLO, R.; ORTEGA-MORA, L. M. Seroprevalence of Neospora caninum infection in dairy and beef cattle in Spain. International Journal for Parasitology, Amsterdam, v. 29, n. 8, p. 1201-1208, 1999.

RAGOZO, A. M. A.; PAULA, V. S. O.; SOUZA, S. L. P.; BERGAMASCHI, D. P.; GENNARI, S. M. Ocorrência de anticorpos anti-Neospora caninum em soros bovinos procedentes de seis estados brasileiros. Revista Brasileira de Parasitologia Veterinária, São Paulo, v. 12, n. 1, p. 33-37, 2003.

SANTOS, R. R. D.; GUIMARÃES, A. M.; da ROCHA, C. M. B. M.; HIRSCH, C. Frequência de anticorpos antiNeospora caninum em bezerras e novilhas de rebanhos leiteiros na microrregião de Lavras, Minas Gerais. Ciência Animal Brasileira, Goiânia, v. 10, n. 1, p. 271280, 2009.
SARTOR, I. F.; GARCIA FILHO, A.; VIANNA, L. C.; PITUCO, E. M.; DAL PAI, V.; SARTOR, R. Ocorrência de anticorpos anti Neospora caninum em bovinos leiteiros e de corte da região de Presidente Prudente, SP. Arquivos do Instituto Biológico, São Paulo, v. 72, n. 4, p. 413-418, 2005.

SCHARES, G.; BÄRWALD, A.; STAUBACH, C.; ZILLER, M.; KLÖSS, D.; SCHRÖDER, R.; LABOHM, R.; DRÄGER, K.; FASEN, W.; HESS, R.G. Potential risk factors for bovine Neospora caninum infection in Germany are not under the control of the farmers. Parasitology, Glasgow, v. 129, n. 3, p. 301-309, 2004.

SILVA, D. A. O.; LOBATO, J.; MINEO, T. W. P.; MINEO, J. R. Evaluation of serological tests for the diagnosis of Neospora caninum infection in dogs: optimization of cut off titers and inhibition studies of cross-reactivity with Toxoplasma gondii. Veterinary Parasitology, Amsterdam, v.143, n. 3-4, p. 234-244, 2007.

SOUSA, M. E.; PORTO, W. J. N.; ALBUQUERQUE, P. P. F.; SOUZA NETO, O. L.; FARIA, E. B.; PINHEIRO JÚNIOR, J. W.; MOTA, R. A. Seroprevalence and risk factors associated with infection by Neospora caninum of dairy cattle in the state of Alagoas, Brazil. Pesquisa Veterinária Brasileira, Rio de Janeiro, v. 32, n. 10, p. 1009-1013, 2012.

SUN, W.-W.; MENG, Q.-F.; CONG, W.; SHAN, X.F.; WANG, C.-F. Herd-level prevalence and associated risk factors for Toxoplasma gondii, Neospora caninum , Chlamydia abortus and bovine viral diarrhoea virus in commercial dairy and beef cattle in eastern, northern and northeastern China. Parasitology Research, New York, v. 114, n. 11, p. 4211-4218, 2015.

TALAFHA, A. Q.; AL-MAJALI, A. M. Prevalence and risk factors associated with Neospora caninum infection in dairy herds in Jordan. Tropical Animal Health and Production, Edinburgh, v. 45, n. 2, p. 479-485, 2013.

TEIXEIRA, W. C.; UZÊDA, R. S.; GONDIM, L. F. P.; SILVA, M. I. S.; PEREIRA, H. M.; ALVES, L. C.; FAUSTINO, M. A. G. Prevalência de anticorpos antiNeospora caninum (Apicomplexa: Sarcocystidae) em bovinos leiteiros de propriedades rurais em três microrregiões no estado do Maranhão. Pesquisa Veterinária Brasileira, Rio de Janeiro, v. 30, n. 9, p. 729$734,2010$. 
